\title{
Developing Indicators for Sustainability of Commodity Associations in Karnataka, India
}

\author{
Raghupathi Dantapur $^{1 *}$, N. T. Naresh ${ }^{2}$, M. Venakatesh ${ }^{3}$ and C. Umashankara ${ }^{4}$ \\ ${ }^{1}$ Zonal Agricultural Research Station, Mandya, University of Agricultural Sciences \\ Bangalore, India \\ ${ }^{2}$ Krishi Vigyan Kendra, Mandya, University of Agricultural Sciences Bangalore, India \\ ${ }^{3}$ College of Agriculture, Mandya, University of Agricultural Sciences Bangalore, India \\ ${ }^{4}$ Directorate of Research, GKVK, University of Agricultural Sciences Bangalore, India \\ *Corresponding author
}

\section{A B S T R A C T}

\begin{tabular}{|l|}
\hline Key w o r d s \\
Commodity \\
associations, \\
Experts rating, \\
Indicators, \\
Marketing, \\
Farm yield, \\
Sustainability \\
\hline Article Info \\
\hline Accepted: \\
12 March 2020 \\
Available Online: \\
10 April 2020 \\
\hline
\end{tabular}

The sustainability of farmer associations is proven index of agricultural development. They are the key link of food chain system. The FAO is encouraging to form the commodity associations for sustainability of agriculture across the world. In line of this, The Krishi Vigyan Kendras of University of Agricultural Sciences, Bangalore, Karnataka have promoted the Commodity Associations. They have been transferring the technologies and supporting the association members for income generating activities. The research study was conducted in Southern Agro-climatic Dry Zone of Karnataka with an objective of finding the indicators of sustainability of commodity associations. The sample size of the study was 120 . The research design was experimental type with control group. The indicators of sustainability were identified by following the procedure of expert rating system. The study found nine indicators; regular sources of funding, banking transactions, production technology support and extension programs, leadership qualities, market linked commodity production, regular meetings and implementations, linkage and cooperation with local and external institutions, less political interference and education share \& care. The utility of the study being, these indicators are the measuring tool to find out the extent of sustainability. By administering these, one can find out the extent of sustainability of commodity association.

\section{Introduction}

The Indian farmers often at risk of uncertainties of unpredicted climatic conditions, production constraints and marketing constraints of produce. The efforts are on working towards sustainability of production by the Govt., and other developmental agencies, to address this, the farmers have been asked to come together to form associations. The sustainability of farmers associations is proven index of agricultural development. They are key link of food chain system.

They produce, process and market the farm produce to earn profits. The FAO is encouraging to form the CAs (Commodity Associations) for sustainability of agriculture across the world. 
The CAs play a key role in giving the valuable feedback of stakeholders, involved in supply, marketing and value chains of product movement from producers to consumers and enabling the Governments to frame or change in policies in the interest of stake-holders' welfare and food security to the people of the State.

It will reduce the middlemen interference in supply of inputs for commodity production and its marketing till it reaches the consumers (Andrew W. Shepherd et al., 2009). The French model suggests inter-professional associations contributed in market regulation, contractual relation, information provision, export promotion, research development, food security and environmental management (Langreo 2002).

In India, the Govt., has taken up several initiatives to involve the farmers as stake holders by formulating the CAs. The Indian Council of Agricultural Research (ICAR) New Delhi, has framed formulation and implementation guidelines to undertake them in all the 700 Krishi Vigyan Kendras through its district level Feeder institutes across India.

With this background, a research study was conducted which was funded by the Directorate of Research, to find out the sustainability of CAs undertaken by Krishi Vigyan Kendras (KVK) of University of Agricultural Sciences Bangalore (UASB).

There were more than 12 CAs were functional from the $7 \mathrm{KVKs}$ of UASB as on 2018. The relevancy of the study is, till recent past the farmers were more concerned about production of food grains but of late, the farmers are worried about marketing their produce and getting remunerative price. Since the market prices are fluctuating based on the supply and demand, the famers were unable to predict the price in the market. Thus, many of the farmers have been getting less remunerative price and incurred losses, this kind of recurring experiences made them to feel farming as a non-profitable occupation.

In order to make the farmers aware about the marketing mechanism, the Government has initiated many pro-farmer market programs to reduce the middlemen interference and encouraged direct marketing.

One among these several initiatives, the formation of CAs is one. The Statement of problem is; the ICAR-UASB has formulated the CAs to support them through technology interventions. After a lapse of few years, some of the CAs were functioning effectively, some of them are slow and less functional.

To ascertain the reasons the UASB wish to know the status of the CAs, their likely level of sustainability promoted by the KVKs, in southern districts of Karnataka as to strengthen them by administering with appropriate technological interventions, for which there is a need to develop indicators for measuring the extent of sustainability. The Objectives of the study was to identify the indicators, for measurement of extent of sustainability of CAs. The research was carried out during 2018-19.

\section{Materials and Methods}

\section{Research design}

Identification of Judges and opinion seeking judges rating method.

\section{Identification of indicators of sustainability}

The procedure of normalized ranking method of Guilford (1954) was adopted. Exhaustive lists of 43 statements related to sustainability of associations were listed after reviewing the literature and seeking the opinion of resources persons in the field of sustainability productions. 
These 43 statements on four point continuum were mailed to 150 experts identified from Universities and developmental departments of India. Among them 31 experts responded by providing complete information.

\section{Secondary sources}

The pertinent information was collected from the institutes, referred literature and reports. Karnataka State Department of Agriculture and Raitha Samparka Kendras (RSK), Zonal Agricultural Research Station records and Schemes, KVK and Dist. Statistics of Govt. of Karnataka, Directorate of Extension UASB. For analyzing the data the statistical tools such as frequency, percentage, mean, standard deviation to draw inference.

Nominal score 3, 2, 1, was assigned for each indicator on a three point continuum and categorized them as "High, Moderate and Less" sustainable level respectively (Table 3).

\section{Results and Discussion}

The results have been discussed according to the objectives of the study, two step procedures was adopted.

\section{To identify the indicators for measurement of extent of sustainability of CAs}

\section{Enlisting items of sustainability}

After reviewing exhaustive literature, 35 items reflecting sustainability of CA statements were enlisted. For calculating the Relevancy and its Weightage (RW) a four point continuum of Most Relevant (MR), Relevant (R), Less Relevant (LR) and Not Relevant (NR) with the nominal score of 4, 3, 2 and 1 , were assigned respectively.

RW=MR $x 4+R x 3+L R x 2+N R x 1$. Such list was sent to 145 experts (specialized in sustainability index development) in the areas of Agricultural extension, Psychology, Sociology Departments of farm and traditional Universities in Karnataka for item relevancy and weightage, 31 experts responded with filled in opinion.

\section{Experts rating and final statements}

The procedure of normalized ranking method of (Guilford 1954) was adopted. The relevancy weightage data received from the experts was tabulated and analyzed. The statements which had more than 0.75 relevancy value were selected. Upon calculating so, there were 13 such statements found to have relevancy and weightage (Table 1 ), out of 35 statements. These statements were ranked.

Later, the statements were subjected to aggregation, based on the similar meaning reflections to avoid duplication and clubbing such similar statements and denoting them as an Indicator. With this procedure, nine indicators were identified (Table 2).

To conclude that, he sustainability indicators for CAs was developed by enlisting of statements of sustainability and seeking the opinion of experts on 4 point continuum of nominal score. Nine indicators reflecting sustainability were identified viz., regular source of funds, banking transactions, production technology support and extension programs, market linked commodity production, leadership qualities, regular meetings and implementations, linkage and cooperation with local and external institutions, less political interference \& affiliations and education and share \& care. These indicators would reveal the sustainability level when administered to the members of CA. Thus, it is a tool to measure the sustainability level. 
Table.1 Experts rating relevancy final statements, weighing more than 0.75 score $n=31 *$

\begin{tabular}{|c|c|c|c|c|}
\hline SI. No & Statements & Mean score & $\%$ & Rank \\
\hline 1. & Effective leadership qualities of executive committee members & 3.75 & 93.75 & II \\
\hline 2. & High level of risk taking ability of members & 3.75 & 93.75 & II \\
\hline 3. & Repayment behavior of loans to the Banks & 3.75 & 93.75 & II \\
\hline 4. & $\begin{array}{l}\text { External support from Gram Panchayat and Government } \\
\text { for the financial and moral support to undertake } \\
\text { developmental activities }\end{array}$ & 3.62 & 90.62 & III \\
\hline 5. & $\begin{array}{l}\text { Lending loans to its members at low rate of interest to meet } \\
\text { their personal, social and economic needs }\end{array}$ & 3.62 & 90.62 & III \\
\hline 6. & $\begin{array}{l}\text { Opportunity for the members to express their opinion and } \\
\text { decision making in the meetings }\end{array}$ & 3.62 & 90.62 & III \\
\hline 7. & $\begin{array}{l}\text { Higher education level and sense of belonging and care among } \\
\text { the members of CAs }\end{array}$ & 3.5 & 87.5 & IV \\
\hline 8. & $\begin{array}{l}\text { The members should be cosmopolite in nature : connect with } \\
\text { outside world }\end{array}$ & 3.5 & 87.5 & IV \\
\hline 9. & $\begin{array}{l}\text { Arranging marketing information and facilities to the produce } \\
\text { by the CAs }\end{array}$ & 3.5 & 87.5 & IV \\
\hline 10. & $\begin{array}{l}\text { Facilitating to get the loans from the banks by the CAs } \\
\text { to its members at reasonable rates builds affinity towards CAs }\end{array}$ & 3.5 & 87.5 & IV \\
\hline 11. & Experience in agriculture production and marketing of produce & 3.37 & 84.37 & $\mathbf{V}$ \\
\hline 12. & $\begin{array}{l}\text { Number of self-employment activities undertaken } \\
\text { by the members }\end{array}$ & 3.37 & 84.37 & $\mathbf{V}$ \\
\hline 13. & Sharing of benefits equitably of CA by all the members & 3.37 & 84.37 & V \\
\hline
\end{tabular}

Table.2 Indicators (after aggregation of judges rated 14 items) of sustainability of commodity associations $n=31 *$

\begin{tabular}{|c|l|c|c|}
\hline Sl. No. & Indicators & Mean Relevancy \% & $\begin{array}{c}\text { Mean weightage } \\
\text { Score }\end{array}$ \\
\hline $\mathbf{1}$ & Regular source of funds & 90.62 & $\mathbf{3 . 6 2}$ \\
\hline $\mathbf{2}$ & Banking transactions & 85.93 & $\mathbf{3 . 4 3}$ \\
\hline $\mathbf{3}$ & Production technology support and & 83.59 & $\mathbf{3 . 3 4}$ \\
\hline $\mathbf{4}$ & Extension programs & & \\
\hline $\mathbf{5}$ & Market linked commodity production & 90.62 & $\mathbf{3 . 6 2}$ \\
\hline $\mathbf{6}$ & Leadership qualities & 87.5 & $\mathbf{3 . 5 0}$ \\
\hline $\mathbf{7}$ & Regular meetings and implementations & 84.37 & $\mathbf{3 . 3 7}$ \\
\hline $\mathbf{8}$ & Linkage and Cooperation with & 83.9 & $\mathbf{3 . 2 1}$ \\
\hline $\mathbf{9}$ & Less political interference & 80.8 & $\mathbf{3 . 1 9}$ \\
\hline *Experts & Education and Share \& care & $\mathbf{7 8 . 9}$ & $\mathbf{3 . 1 6}$ \\
\hline
\end{tabular}


Table.3 Categorization of sustainability

\begin{tabular}{|c|c|c|}
\hline Sl. No. & Score range & Extent of Sustainability \\
\hline $\mathbf{1}$ & 9 to 14 & Less \\
\hline $\mathbf{2}$ & 15 to 20 & Moderate \\
\hline $\mathbf{3}$ & $\mathbf{> 2 1}$ & High \\
\hline
\end{tabular}

(Maximum average score: 4 and minimum average score 1 of opinion rating continuum)

\section{Acknowledgement}

I thank Dr. Umashankar. C., Co-PI \& Associate Professor (Ag. Economics) Directorate of Research GKVK UASB, Dr.Naresh, N.T., Co-PI \& Scientist (Agril. Extension), KVK, Chamarajanagar and Dr. Savitha C.M., Co-PI and Associate Editor, Communication Centre, GKVK, UASB and Dr. Venkatesha M, Associate Professor of Horticulture, for their regular involvement and offering technical suggestions at the various stages of the project. I thank all the Sr. Scientist \& Heads and the Scientists of KVKs of Hassan, Mandya, Tumkur, Chamarajanagara and Ramanagaram for their cooperation and support extended in collecting data from the respondents.

\section{References}

Andrew W. Shepherd, jean-Joseph Cadilhon and Eva Galvez, 2009. Commodity Associations: A tool for supply chain development? Food and Agriculture Organization of the United Nations Rome.

Bharamappanavara, S.C., 2013. Growth and outreach of Self-help groups microcredit models in India: A literature insight. Int. J. Social and Econ. Res., 3(1): 1-14.

Chaithra G. J. and Shivalingegowda N. S., 2017. Development of an index on Sustainable Development of SHG Members and their Level of Sustainability. Mysore. J. Agric. Sci., 51 (2): 303-308.

Guilford, J. P., 1954, Psychometric methods. Tata McGraw-Hill Publishing Co. Ltd., New Delhi.

Langreo, A. 2002. Las organizaciones interprofessionales como instrumentos de vertebracion sectoral. Libro blanco de la agricultura y el desarrollo rural. Jornada Tematica "La vertebracion de sctores: interlocucion sectorial". Madrid, 17-10-2002.

Nifussi, J and Aznar, O. 2007. Extrnalities, institutions et services. Ie cas de $\mathrm{P}$ agriculture. Working paper. UMR Economic publique. INA P-G, Paris.

Sridhar N., 2012. Self-help groups performance in India. J. Economics and Management.1:8.

\section{How to cite this article:}

Raghupathi Dantapur, N. T. Naresh, M. Venakatesh and Umashankara, C. 2020. Developing Indicators for Sustainability of Commodity Associations in Karnataka, India. Int.J.Curr.Microbiol.App.Sci. 9(04): 1327-1331. doi: https://doi.org/10.20546/ijcmas.2020.904.157 